\title{
Practices of English Training for Faculty of Business College in the Context of Obtaining International Accreditation
}

\author{
Xia Xu \\ Business College of Beijing Union University, Beijing, China \\ xuxiajy0209@163.com
}

\begin{abstract}
International business colleges have higher requirements on the English for their faculty. From the faculty's needs to improve English proficiency, this paper makes surveys and analyzes the needs of English training for faculty, and proposes corresponding suggestions based on current training situations to ensure that faculty can continuously improve their English and keep pace with the development needs of the college.
\end{abstract}

Keywords: Business College, faculty, English, training. 


\section{Introduction}

With the globalization and the development of higher education, English proficiency, for university faculties, is beneficial not only to their improvement in teaching, professionalism and research, but also to their personal overall development. And the business college in the international certification environment, has higher requirements on English for faculties. In AACSB certification, Business College of Beijing Union University has the development vision: to become a globally integrated business school that is highly valued by the regional community. We hope that the students of business school will become the backbone of the business community with a sense of social responsibility, international vision and business practice ability. To enhance the international vision, educators should first improve their English. English training is one of the effective means to improve English proficiency.

English training for faculty is a systematic process that involves a series of steps from identifying needs, defining objectives, selecting teaching materials and methods, and evaluating the effectiveness of training. Therefore, combined with our college's actual demands of faculty's English proficiency in the process of earning the international accreditation, we need to set specific educational objectives, curriculum, organizational forms, teaching methods and evaluation and assessment criteria and greatly improve the effectiveness of training, which will not only help improve faculty's English proficiency, but also effectively facilitate the implementation of College's efforts for accreditation.

\section{Demands for English Proficiency of the Business College's Faculty}

After launching international programs, Business College has paid particular attention to improve improving faculty's English, including English teachers, allEnglish teachers and bi-lingual teachers. Each year, a specific amount, more than $50 \%$, of faculty training funds is allocated to support English training. Especially since the application for AACSB accreditation, AACSB accreditation requires to form a sufficient and qualified teaching team capable of achieving the college's mission to complete the college's strategic planning, and also requires corresponding positions to provide a guarantee for the completion of the college's mission.

The iSER that Business College submitted in 2016 was successfully approved by the IAC of AACSB, ushering the application for AACSB accreditation into a new stage, from top-level design, strategic planning and step-by-step demonstration to down-to-earth implementation. All-English teaching and students' excellent English have featured Business College. When teaching fundamental college English courses, bilingual courses or all-English teaching, teachers' English proficiency and communication skills will affect students to learn English and professional 
knowledge. In addition, in the process of obtaining AACSB accreditation, the whole college should use English as the main language to communicate with foreign experts, receive them who would come in the later process and report the work. Therefore, faculty's English proficiency plays an essential role in earning the AACSB accreditation. And the proficiency cannot be improved in a night but gradually.

\section{Surveys of Training Needs for English Proficiency}

Only when we fully understand the needs and learning objects of faculty's English learning and combine them with English learning characteristics can we offer targeted help and support for them to choose proper English training methods and achieve expected training goals. By various ways of surveys like informal discussions with representatives from the faculty, individual interviews, questionnaire, we have learned about their specific needs and learning situations in English trainings. $83 \%$ of college's professional teachers are doctors and in the fulltime teachers, the rate is $62 \%$. Teachers that have a foreign degree or experience of overseas visit study account for $60 \%$. They have a good foundation in English. Through the surveys, the needs of college faculty's English training needs can be mainly divided into three kinds: for professional English teachers responsible for college English and core courses about international business in English, they need training in spoken English and IELTS; for all-English and bi-lingual professional teachers with a doctoral degree that have little problem with reading and writing for core courses, they have difficulties in spoken English and pursue more idiomatic and fluent spoken English; for faculty members with international work, they are most masters capable of reading English literature on their work while the application of AACSB accreditation involves reading accreditation criteria, receiving and communicating with experts in English so they aims to improve spoken English for daily communication in a short time, successfully finish their tasks of helping AACSB experts to visit our campus for evaluation and passingly promote their English proficiency.

\section{English Training Situations}

As the process of obtaining AACSB accreditation advances, the college has continuously taken advantage of diversified ways to satisfied the training needs of the above three kinds of teachers. Professional English teachers, all-English teachers and bi-lingual teachers take various English training supported by our university's special funds. Since 2013, there have been special funds from faculty development funds to support the backbone of English, all-English and bi-lingual teachers to participate in specialized English trainings including IELTS, XDF English. With focuses and alternate teaching methods, the above trainings can cultivate the outstanding teaching talents. However, due to financial constraints, 
those trainings have limited benefits and are difficult to follow up continuously while teachers do need to gradually accumulate knowledge and improve their English proficiency and short-term trainings make little difference. For managerial personnel, based on their working features and English capabilities, the college has attempted to adopt the model of group training of different levels and organized four sessions of training employing Chinese teachers, English teachers and using alternate teaching methods.

\section{Suggestions for Training}

English learning has its own features that it should be continuously reinforced and that intermittent trainings are not conducive to consolidate knowledge. Combining these features with our faculty's learning situations, we propose the following suggestions for English Training.

\subsection{For Professional English Teachers, all-English Teachers and Bi- lingual Teachers}

In addition to making full use of limited funds to support offline individual trainings, online one-on-one, one-to-many models can be adopted to improve English proficiency, especially spoken English. Online one-on-one apps such as 51 talk have been popular, on which teachers can communicate with foreign teachers to improve spoken English, and have discussions about professional knowledge to promote English proficiency about their professions. Also, teachers are encouraged and supported to use new media and employ sustainable and accumulating learning methods, such as the short lessons in Wechat mini programs, joining Wechat groups for learning spoken English and reading and using Tomato English to "see the world, learn spoken English". English Liulishuo is helpful to intensively read foreign periodicals and practice reading skills. These learning methods of new media feature the model of making small progress and repeating learning, which conform to people's learning characteristics and are easy to follow. They are more effective than attending one or two trainings every week and have lower training fees. In addition, teachers can use their spare time to learn and take advantage of clocking in on Wechat to enhance their persistence and exert an impact on colleagues to learn together, supervise each other to improve learning.

\subsection{For Managerial Personnel}

From the previous four group trainings for managerial personnel, employing foreign teachers, conducting group learning and offering trainings of different levels according to their English proficiency have achieve great progress. Continuous alternative trainings can consolidate what they have learning and scenario simulation and role play can rehearse the process of receiving foreign guests. To be specific, in accordance with their English proficiency, there were primary, intermediate, advanced class with learning objects of corresponding difficulty. The 
primary class focuses on daily conversations. The intermediate class aims to gain the skills at receiving guests while the advanced class attempts to make fluent English speeches. After our trials, scenario simulation is the most proper way for group training, where teachers can practice spoken English in diversified and designed scenes to increase English output and consolidate their progress. At present, the major problem of group training is how to plan the learning content and find proper foreign teachers. The pay for foreign teachers from cooperated training agencies is gradually increasing and the flow of foreign teachers is relatively fast, leaving the managerial personnel and foreign teachers adapting to each other all the time. Also, managerial personnel are encouraged to use new media to practice spoken English and make gradual progress.

All the above is our consideration about some basic ways of English training based on college's development goals and teachers' needs. We will try more ways and organize other trainings to improve faculty's teaching and research capability and explore proper ways to assess and evaluate training effects to ensure teachers' progress.

\section{References}

Chen X. (2011). The needs, goals and Strategies of College Teachers' English Training -- Taking school-based training as an example, 29, 187.

Li Y. (2011). Analysis of English training needs of young college teachers: a case study of school-based training in Anshan Normal University. China E-education, 3, 39.

Sun M. (2016). A survey on the current situation of College Teachers' English Training -- a case study of Henan Province. Foreign Language Education Technology, 4, 77.

Zhao J. (2017). Research on situational teaching method in civil aviation flight English teaching. Science and Technology Information, 13, 131. 